\title{
Legal problems of the use of orphan works in digital age
}

\author{
Associate professor Vira TOKAREVA ${ }^{1}$ \\ Professor Iryna DAVYDOVA ${ }^{2}$ \\ Associate professor Elena ADAMOVA ${ }^{3}$
}

\begin{abstract}
The aim of this paper is to consider the mechanisms of legalization of use orphan works, based on a comparative analysis of the legal regulation in the United States, the EU and European countries; identify priority ways to reform and to develop proposals for improving copyright law in Ukraine. In the first section the concept of the orphan works and the circumstances which caused emergence of the orphan works are revealed. It has been established that the problem of orphan works mostly concerns works whose authors died and heirs cannot be found. In the second section the models of legalization of orphan works in the United States, Canada, the EU and European countries are analyzed and these interferences formed a proposal for Ukrainian legislation. In the third section the background of development of legislation of orphan works in Ukraine are studied. The necessity to study the legal regulation of the United States, the EU and European countries in light of the recodification of the Civil law of Ukraine and seeking way of its renovation is substantiated. Developing effective mechanisms of using orphan works are stated to become relevant in the process of digitization of libraries' collections and to have gained a new momentum in recent years. Its result has been provided open access to the works on the Internet.
\end{abstract}

Keywords: intellectual property rights; copyright; collective licensing agreement; digitization; European Union; orphan works.

JEL Classification: K15, K24, K49

DOI: $10.24818 / \mathrm{TBJ} / 2021 / 11 / 3.03$

\section{Introduction}

Cultural institutions such as libraries, museums are in favor of digitization unique material sources recorded on traditional media, in order to preserve their funds and provide open access to these sources to society. Open Access to the funds of cultural institutions become up to date in the context of the outbreak and the derogation access to its' funds.

\footnotetext{
${ }^{1}$ Vira Tokareva - Civil Law Department of the National University “Odessa Law Academy”, Ukraine, https://orcid.org/0000-0002-8409-1477, vera_tokareva@ukr.net.

2 Iryna Davydova - Civil Law Department of the National University "Odesa Law Academy” (Odesa, Ukraine). https://orcid.org/0000-0001-5622-671X, divo-ira@ukr.net.

${ }^{3}$ Elena Adamova - Civil Law Department of the National University "Odessa Law Academy" (Odesa, Ukraine). https://orcid.org/0000-0002-6389-1192, elena.adamova2010@gmail.com.
} 
One of the necessary measures on the way of providing open access to cultural institutions is development of online libraries. Using digital books instead of the printed edition change the libraries' form, when "paper" libraries' funds are digitized, and digital versions are made available to readers ${ }^{4}$.

The transformation of paper library funds has been very slowly. There are numerous obstacles to transfer libraries into digital ones, related to copyright law. The cultural institutions are required to strictly comply copyright law. The limited access to the orphan works of cultural institutes' funds and archives are thought to exclude the possibility to use it legally and its free turnover.

The exclusive rights of work are considered to obtain permission of a rights holder for any kind of using of work, such as reproduction, digitization, translation, processing, etc. The works of the authors' which cannot be identified, in respect of which the copyright has probably not expired and the copyright protection is spreading are commonly called - orphan works. Usually, orphan works belong to the authorship of bad known authors and they are interested to scholars in order to provide further researches. Due to the lack of data of a rights holder, a significant part of the works which could be made available to the users being an undefined legal status. Hereby the lack of data to rights holder of the works is a significant obstacle to digitization and open access to the cultural heritage.

The orphan works are not included to the public domain and the culture heritage, therefore cannot be used freely. In addition, the work happens not to be able to participate in turnover, not to be in demand and not to be an object of inspiration. So, rights holders lose profit of using works and society lose the benefits of open access to cultural heritage. Moreover, orphan works are believed to prevent the author's self-expression, to lead to unintentional censorship and to rise level of breach the copyright law even in case of non-commercial using.

In addition, the legal use of orphan works by prospective users requires conducting diligent search to indicate and locate a rights holder, which is time consuming and usually not effective. Factors such as significant costs of conducting diligent search and the likelihood infringement unknown authors led to avoid orphan works, even if a rights holder of orphan works do not exist and do not object to the use of their works. Taking into consideration the risk of copyright infringement, cultural institutions may not carry out digitization of works without permission of copyright authors. Moreover, the existence of orphan works prevents free copyright expression, may led to unintentional censorship and rising of numbers of copyright infringements.

Thus, the main problem of legalization of the orphan works is due to the fact that it is not possibility to find, identify a rights holder and there is a high-risk probability that the copyright protection of work has not expired and there is a likelihood of claims for copyright infringement by a rights holder.

4 Козлова Н.В., Косовец А.А., Ворожевич А.С. Электронные библиотеки научнообразовательных организаций: правовые проблемы создания и деятельности. Вестник Московского университета, 11 (6), 2015, 50-64. [Kozlova, N.V., Kosovets, A.A., Vorozhevich, A.S. Electronic libraries of scientific and educational organizations: legal problems of creation and activity. Moscow University Bulletin. Series 11. Law, (6), 2015, pp. 50-64]. 


\section{Analysis of recent research}

The study of legal regulation of intellectual property rights, open access to the cultural institution funds and the legalization of the orphan works are reflected in papers of the following scholars: Antopolsky, Efremenko, Borghi, Hansen, Erickson, Favale, Kozlova, Kosovets, Vorozhevich, Levova, Vynnyk, Moyseeva, Lifshitz-Goldberg, Mikhailov, Puzin, Ruzakova, Grin, Ryden, Siso-Calvo, ArqueroAvilés, Marco-Cuenca, Cobo-Serrano.

Significant contribution to the development intellectual property framework in era of digital technology were made in A Review of Intellectual Property and Growth by Professor the University of Wales Hargreves (2011) prepared by the request of the British government ${ }^{5}$.

The Review is considered to have made an impact on solving the problem of orphan works in the whole EU. The Review sets the goal of developing creative industries, the effectiveness of copyright system and the economic growth in digital age and way of its achieving.

Research of using of the Information technologies in the field of intellectual property was conducted by Goldenfein and Hunter. The main idea of the paper is to find effective legal mechanism to solve problem of emergence of orphan works. Australian professors propose to promote blockchain technology to solve the problem of the orphan works and public domain. Using distributed ledgers and artificial intelligence are proposed to automate diligent search of an author by Scholars.

Legal models of using orphan works in the United States, the EU are revealed in the study of Siso-Calvo, Arquero-Avilés, Marco-Cuenca, Cobo-Serrano. Scholars provided systematic review of legal regulation and scientific literature of domestic and international authorities in the light of mass digitization in the field of intellectual property rights.

The Interview with American academic and founder of Creative commons licenses Lawrence Lessig should be mentioned.

The lecturer paper of the Orphan works of Lifshitz-Goldberg, from Hebrew University Jerusalem for WIPO was analyzed.

General and special methods of scientific research were used in process of research. The use of the comparative law research method provided an opportunity to explore the mechanisms for ensuring legal access to orphan works in the EU, the US and other countries. Comparison method helped to identify similarities and differences of the legal regulation in the US, the EU and other countries.

Using the dialectical method, the social factors that influenced on the adoption of regulations to regulate civil relations regarding the use of orphan works and identify problems in the use of orphan works on legal grounds are considered. The use of the dialectical method contributed to the identification of factors contributing to the genesis of such works.

\footnotetext{
${ }^{5}$ Hargreaves, I. Digital. Opportunity. A Review of Intellectual Property and Growth. An Independent Report. May 2011, [online], available at: https://orca.cf.ac.uk/30988/1/1_Hargreaves Digital\% 20Opportunity.pdf_[Accessed 13 May. 2021].
} 
The application of the formal-logical (normative-dogmatic) method provided an opportunity to analyze the legal acts which established requirements for the lawful using of orphan works. The application of the method of logical analysis and dogmatic interpretation of legal norms helped to formulate the conclusions of the study and proposals for improving the legislation.

\section{Results and discussion}

\subsection{The causes of the orphan work emergence}

To use the works whose authors are not known, as well as the using of works whose authors are known, requires the consent of rights holder. However, due to the absence of data about an author and a rights holder, it is impossible to obtain permission from them. It is unable to identify or locate a rights holder when the exclusive copyright still exists and copyright protection has not expired, what means a high probability of being sued by a rights holder ${ }^{6}$. The lawsuit is likely to be file by a rights holder, who may suddenly appear, lead to the fact that the authors avoid to use the works whose authors are unknown. Even if such a probability is insignificant, such actions violate the copyright laws ${ }^{7}$.

Scholars defined orphan works as works whose copyright holders have not been identified, there is no information about location of the right holders, despite a diligent search, reasonable and sufficient measures to identify the copyright holders of the works ${ }^{8}$.

Orphan works are reported to be a significant part of the archives not only libraries, but also of film funds, audio archives and museums. Any attempt to determine the exact number of the orphan works stored in cultural institutions is approximate. The British Library is estimated to contain over $40 \%$ works of its fund the copyrighted works. It is approximately 150 million works whose authors are unknown. Most works have not commercial value, but they are culturally and educationally valuable 9 .

According to estimates by The Center for the Study of the Public Domain at the Duke Law School, the most of the works of twentieth-century cultural heritage

${ }^{6}$ Hansen, David R., Orphan Works: Causes of the Problem (April 10, 2012). Berkeley Digital Library Copyright Project White Paper, 3, 2012, [online], available at: SSRN: https://ssrn.com/abstract=2038068.

${ }^{7}$ Токарева В.О. Окремі аспекти сирітских творів в умовах інтегращійних процесів, Jurnaluljuridic, 3 , 2019, c. 97-101 [Tokareva, V.O. Some aspects of orphan works in the context of integration processes. Jurnaluljuridic, 3, 2019, pp. 97-101].

8 Піхурець, О.В., Розвиток правового регулювання відносин, пов'язаних із використанням "сирітських творів" в Украӥні та краӥнах Європейського Союзу, "Науковий вісник Ужгородського національного університету", 44(1), 2017, C. 81-86. [Pihurets, O.V., Development of legal regulation of relations related to the use of "orphan works" in Ukraine and the European Union, "Scientific Bulletin of Uzhhorod National University", 44(1), 2017, pp. 81-82].

9 Антопольский А.Б., Ефременко Д.В. Инфосфера общественных наук России: монография. Берлин: “Директ-Медиа”, 2017, [Antopolsky, А.B., Efremenko, D.V. Infosphere of social sciences of Russia: monograph. Berlin: Direct-Media, 2017]. 
may be orphan works. The transfer of orphan works to the public domain without the risk of being sued by rights holder is considered to have been published 140 years $\operatorname{ago}^{10}$.

Such works as letters, diaries, maps, educational and scientific texts cannot be published and opened access to them online, or included to miscellanea. For example, a scholar may refrain from researching old photographs for of the significant cost of conducting diligent search and the risk of being sued. Preservation of data by the library through the digitization raises the question of the legitimacy of using works with unknown author. Thus, the British Library stores thousands of photographs of British servicemen from the First and Second World Wars. Due to the inability to track data on a rights holder, despite the historical and cultural value of such works, it cannot be digitized and made available to society ${ }^{11}$.

There are number of factors contribute to the emergence of orphan works:

- data about the author of the work happened to have lost, if the work exists in a single copy and data can be lose due to negligence of cultural institutes' stuff for inappropriate storage. Although, copying and using the work with no cite or specified the author, and the original was lost. Especially it happens when the works are copied on the Internet;

- negligence of authors to their copyrights and the object of their creativity;

- co-authored a large number of authors who do not know each other, which contributes using the Internet, such as the creation of Wikipedia, open-source software, so write millions of entries in blogs and social networks. Under such conditions, it is difficult to know the name or nickname of all authors, but even to establish clear criteria for the authorship of each of these co-authors;

- long terms of copyright protection (70 years) and the tendency to it extends;

- voluntary state registration of copyright works and the absence of its mandatory ${ }^{12}$.

In some point the problem of orphan works and prevention its occurrence in the future is supposed to solve by providing mandatory registration of copyright works. Nevertheless, the postulate of the copyright law is stated to provide copyright protection for works without of any formalities. The Berne Convention for the Protection of Literary and Artistic Works (1886) states that the exercise of copyright

${ }^{10}$ Center for the Study of the Public Domain, Duke Law School [online], available at: http://www. 1aw.duke.edu/cspd/orphanworks. Html [Accessed 10 May. 2020].

${ }^{11}$ Lifshitz-Goldberg, Y., Orphan Works. WIPO Seminar. Lecture Summary, 2010, [online], available at: http://www.wipo.int/edocs/mdocs/sme/en/wipo_smes_ge_10/wipo_smes_ge_10_ref_theme11_ 02.pdf [Accessed 14 May. 2021].

12 Піхурець О.В. Проблеми використання "сирітських творів", Проблеми цивільного права та процесу: тези доп. учасників наук.-практ. конф., присвяч. світлій пам'яті О. А. Пушкіна, Харків: ХНУВС, 2017. С. 201-204. [Pihurets, O.V. Problems of using "orphan works". Problems of civil law and civil process: abstracts of reports of participants of the scientific-practical conference dedicated to the memory of OA Pushkin, 2017, pp. 201-204]. 
shall not be subject to any formalities (Art. 5). Voluntary registration of copyright objects is a guarantee of balance of the interests of authors and users ${ }^{13}$. This copyright principle makes possible to distinguish the patent property protection from the copyright protection, so it must be preserved. The mandatory registration of copyright object does not correspond both the provisions of the Berne Convention and the legislation of countries of the Romano-Germanic legal system, and the history of the copyright ${ }^{14}$.

Circumstances which may cause the existence of orphan works is the author's moral right to use a pseudonym or to publish works anonymously. Hence the absence of data of the author is not allow to use the works freely.

It requires the user to take certain actions to obtain permission until the work enters the public domain. The long term of protection of works whose authors are unknown for objective reasons which is fifty years after the work has been lawfully made available to the public (Art. 7 (3) The Berne Convention).

It is not possible to find the author's heirs both after 50-60 author's death and after a short period of time after his death. Moreover, there are difficulties with the protection of well-known authors, the protection of the rights of those who are unknown or died without leaving heirs is obviously problematic.

At the same time, the evolution of technological means and tools has a significant impact on developing copyright law ${ }^{15}$. The role of the publisher seems to lose its relevance for providing the work in the digital age when Internet users posted their works on social media apps and platforms.

In some extent the problem of identifying authors on the Internet is solved by using Creative Commons licenses terms, which allow authors to choose the terms and conditions of using the works. Nevertheless, the problem of authorship on the Internet is still exist in the case of collective authorship ${ }^{16}$.

Besides that, according to the Handbook on Copyright and Related Issues for Libraries (2009), the problem of orphan works concerns as works whose authors

${ }^{13}$ Штефан О. О. Правовий режим використання сирітських творів "Міжнародний науковий журнал «Інтернаука", 2(2), 2017, C. 184-191 [Shtefan, E.E., Legal regime of use of orphan works, International scientific journal. Internauka, 2, 2017, pp. 184-191].

14 Михайлов, К., Сиротские произведения: в поисках правового режсима. Право интеллектуальной собственности: Сб. науч. тр. Центр социал. науч.-информ. исслед. Москва, 2017, С. 5965.[Mikhailov, K., Orphan works: in search of a legal regime. Intellectual Property Law: Scientific Digest, Center for social. scientific-inform, Moscow State University, 2017, pp. 59-65].

15 Kyryliuk, A., Baadzhy, N., Honhalo, R., Kapustina, N., \& Galupova, L. (2019) Protection of copyright on the Internet. Amazonia Investiga 8(24), 464-470; Давидова I.В. Блокчейн та категорія правочину. Актуальні проблеми иивілістики у иифрову добу. за ред. Є.О. Харитонова, О.I. Харитонової. 2018, С. 59-92 Одеса: Юридична література, [Davydova, I.V. Blockchain and transaction category. Actual problems of civilization in the digital age. Edited by Kharytonov, U.O., Kharytonova. 2018, pp. 59-92, Odessa: Legal Literature].

${ }^{16}$ WIPO, 2011, Interview with Lawrence Lessig. WIPO Magazine [online], available at: https://www. wipo.int/wipo_magazine/ en/2011/01/article_0002.html [Accessed 30 May. 2021]; Hansen, David R., Orphan Works: Definitional Issues, Berkeley Digital Library Copyright Project, White Paper, 1, 2011, [online], available at: http://ssrn.com/abstract=1974614. [Accessed 5 june. 2021]. 
died and heirs cannot be found as materials with unknown authors on the Internet ${ }^{17}$. Prospective user has to obtain permission to use the work published in platforms and the websites as well, but due to an outdated e-mail address listed on the website a rights holder cannot be found. As the users are around the world, any attempt to search a rights holder can be quite challenging.

Due to the transnational nature of the Internet and the dissemination of a copyright works is ensured by the latest technologies, solving the problem of orphan works must be solve at the interstate level.

\subsection{Solving the problem of the orphan works in the United States of America, Canada and the $\mathrm{EU}$}

The American experience of legalizing orphan works is still under construction. In the United States, the Orphan Works Project (OWP) has been running as part of the private Google Books Search (GBS) project launched by Google since $2004^{18}$. The project allows students, faculty, and other authorized visitors to work with the full text of universities' books. The number of users working with a book at the same time was limited by the number of copies of such a book available to the library. A number of actions had been taken before the book were included to the list of orphan works. To begin with, it was studied whether the book was available for sale and whether the prospective user made attempts to locate and identify a rights holder. If a rights holder was not identified and located, the work added to the list of "candidates" works which was posted on the HathiTrust website for 90 days. If applications or objections were not received after this period, the work matched as an orphan. According to organizers, the project has weak point and it does not exclude erroneous conclusions.

In a 2006, the Copyright Office provided recommendation to conduct diligent search to find a rights holder before using works with unknown authors. If a rights holder sued against user when orphan work had been republished, the "reasonable" compensation might be paid. Such compensation is not recognized as statutory damages for copyright infringement but civil compensation. Hereby, the using of orphan works is not recognized as violation of law in certain circumstances if the law is respected.

The decision in the case of Authors Guild et al. vs. Google ${ }^{19}$ (2011) seems to effect to use orphan works legally in the United States. Digitization of cultural

17 Handbook on Copyright and Related Issues for Libraries, 2009 [online], available at: https://eifl.net/sites/default/files/resources/201 409/handbook_rus_05.pdf [Accessed 10 May. 2021].

18 Проект Google Books - несостоявшаяся революция в авторском праве? last modified November 21, 2012 [Is the Google Books project a failed copyright revolution?] 2012, [online], available at: http://lexdigital.ru/2012/069/ [Accessed 11 May. 2021].

19 Authors Guild, Inc. v. Google Inc., No. 13-4829-cv (2d Cir. Oct. 16, 2015) [online], available at: https://fairuse.stanford.edu/ case/ authors-guild-v-google-inc/ [Accessed 28 May. 2021]; Randal C. Picker, The Google Book Search Settlement: A New Orphan-Works Monopoly? Journal of Competition Law and Economics, 5 (3), 2009, pp. 383-409. 
institutions' funds for preservation and to ensure its open access via Internet are considered to base on fair use doctrine in accordance with the court decision. This means the ability to use orphan works without asking permission from the author.

Breakthrough of orphan works regulation in the United States was the report of "Orphan Works and Mass Digitization" presented in 2015 by the US Copyright Office which contain an optional proposition in this field ${ }^{20}$. Minimum diligent search is reported to conduct in the records of the Copyright Office and the using remedies are stated to limit if user can prove that he or she provided diligent search in good faith for each works and a rights holder could not be identified.

The proposed provisions of using orphan works have been criticized for introducing diligence search instead of applying for fair use doctrine. The main critics is the sufficient cost to locate a rights holder, which may exceed the useful benefits of using orphan works. In addition, the user is non-independent from an unknown person. As the report stated to register for users the Copyright Office instead of instead of forcing the authors to register,) That is way the works with unknown author are proposed to call "hostage works" instead of orphan works ${ }^{21}$.

The formation of copyright in the United Kingdom and the United States are considered to have influenced by Canadian law, where licensing scheme were established for using orphan works in condition to conduct diligent search ${ }^{22}$.

Although Canada isn't in favor of large-scale digitization, the law provides mechanisms of non-exclusive licensing of orphan works. The user must demonstrate attempts which made to locate and identify the author and if the author cannot be found, the license may by applied to the Copyright Board of Canada.

The Copyright Board of Canada gives assent to use works, nominate the licensing fee and the terms of use orphan works. The licensing fee is imposed in favor of a collective organization, if a rights holder of the orphan work does not appear within five years, the organization can keep payment fee. If the copyright owner does not receive a license fee, the collecting society may leave fee. ${ }^{23}$

Both the licensing scheme and the limited liability scheme require to conduct diligent search before using work. The difference between them is that licensing system provides application of the user to obtain a license before using the work, which is similar to insurance against the claim of a copyright owner.

${ }^{20}$ U.S. Copyright Office, Orphan Works and Mass Digitization. A report of the register of copyrights, June, 2015. [online], available at: www.copyright.gov_Accessed 30 May. 2021].

21 Левова И.Ю. Сиротские произведения в России: статус, пути решения проблемь, Общественное достояние. Как открыть доступ к культуре и знаниям: сборник, М.: Екатеринбург: Ассоциация интернет-издателей, 2016. C. 49-88, [Levova, Y.Yu., Vynnyk, D.V., Moyseeva, A.Yu. Orphan works in Russia: status, ways to solve the problem. Yekaterinburg: Association of Internet Publishers, 2016, pp. 49-88].

22 Пузин, Р.С., Проблема перехода сиротских произведений в общественное достояние “Вестник Самарской гуманитарной академии”, 1 (20), 2018, pp. 152-160 [Puzin, R.S. The problem of the transition of orphan works to the public domain. Bulletin of the Samara Humanitarian Academy, 1(20), 2018, pp. 152-160].

${ }^{23}$ Lifshitz-Goldberg, Y., Orphan Works. WIPO Seminar. Lecture Summary, 2010, 
Conducting diligent search of a collection of works is costly and may detain and delay the publication of the work. As the diligent search is carried out by the institutions centrally, in order to reduce the financial costs, scientists proposed to use a decentralized method based on crowdsourcing and involving volunteers to carry out certain steps of the procedure. Involving a significant number of participants can help allocate costs. It may help cultural institutions to act in accordance with the law $^{24}$.

The terms of the collective licensing agreement must be flexible enough to be up to date, to enable businesses, authors, consumers and scientists encourage to use copyright sources without fear to be sued ${ }^{25}$. In his opinion, an extended collective licensing paid for by the government may solve the problems of using works with unknown authors.

The first step on the way of using orphan works in the European community was made when The Memorandum of Understanding key principles on the digitization and making available of out-of-commerce works was passed in $2011^{26}$. The Memorandum is the agreement between libraries one the one hand and a rights holder on the other hand which provide voluntary licensing agreement. The works are stated to be out-of-commerce on condition of copyright protection and absent of a commercial interest to publish it. Providing mandatory licensing procedures is claimed to grant licenses to libraries and other cultural institution to provide the digitization to works of their collection. After these procedures cultural institutions may conduct the digitization and open access to works of their collection for noncommercial purposes.

As the Member States adopted different models of legal regulation of orphan works in the national legislation, in order to obtain unify approach in this field Council of Europe adopted Directive 2012/28/EEC on certain permitted uses of orphan works, which entered into force on 28 October $2012^{27}$.

According to Art. 2.1. of Council Directive 2012/28/EEC "On certain permitted uses of orphan works" orphan works are works in respect of which a rights holder has not been identified or the location of the identified rights holder cannot be established, despite diligent search.

\footnotetext{
${ }^{24}$ Borghi, M., Erickson, K., Favale, M. With Enough Eyeballs All Searches Are Diligent: Mobilizing the Crowd in Copyright Clearance for Mass Digitization, 2016, 16 Chi. -Kent J. Intell. Prop. 135 available at: http://scholarship.kentlaw.iit.edu/ckjip/vol16/iss1/6.

${ }^{25}$ Ryden, J. Legal restrictions and the digital library - is digital access to knowledge achievable? The IFLA World Library and Information Congress, August 28, 2013, [online], available at: http://library.ifla.org/223/13/198-ryden-en.pdf [Accessed 18 May. 2021]; Allard Ringnalda, Orphan Works, Mass Rights Clearance, and Online Libraries: The Flaws of the Draft Orphan Works Directive and Extended Collective Licensing as a Solution, Medien und Recht International vol. 8, 2011, pp. 3-10, [online], available at: https://ssrn.com/abstract=2369974.

${ }^{26}$ European Commision, The Memorandum of Understanding (MoU) key principles on the digitization and making available of out-of-commerce works, 20 September 2011, [online], available at: https://www.jipitec.eu/issues/jipitec-2-3-2011/3180/mou.pdf [Accessed 27 April. 2021].

${ }^{27}$ European Parliament and European Council, Directive of 25 October 2012 On certain permitted uses of orphan works [online], available at: https://www.eifl.net/resources/european-orphan-worksdirective-eifl-guide [Accessed 17 May. 2021].
} 
The provisions of Council Directive 2012/28/EEC apply to the following objects: (1) works published in the form of books, periodicals, newspapers, magazines or other works in the collections of public libraries, educational establishments or museums, as well as in the collections of archives, film or audio funds; (2) cinematographic or audiovisual works and phonograms held in the collections of public libraries, educational establishments or museums, as well as in the collections of archives, films or audio funds; and (3) cinematographic or audiovisual works and phonograms created by public service broadcasters up to and including 31 December 2002 and placed in their archives. Hereof this model of the legalization of orphan works also known as statutory exception-based model, as it contains objects which covered by Directive and excluded works ${ }^{28}$.

Beside the adoption of Directive 2012/28 it's have been criticized for its disadvantages and limited scope of application. Photographs and other images have not yet received the status of orphan works in accordance with Directive 2012/28. The distribution of the orphan works has allowed only to non-profit cultural institutions such as libraries, museums, archives, educational institutions, film and audio collections, publishers and public service broadcasters based in EU Member States, etc., in accordance with Directive 2012/28 (Article 1).

The Directive included provision of the announcement of a rights holder if the author is found and the termination of an "orphanage" status of the work. Besides, it does not contain a procedure for the transfer of orphan works to the public domain if a rights holder is not identified or located. National copyright systems are limited to describe the transition of works to the public domain after the end of the term of protection ${ }^{29}$.

To get permission for using orphan works requires to conduct a minimum diligent search of a rights holder in databases determined by each EU Member State in consultation with rights' holders and users (Art. 3 Directives 2012/28). The list of database contains in the Annex of the Directive created for the search of works by EU Member States. This provision means that The Council Directive 2012/28/EEC encourages the Member States to take necessary steps to ensure that information of orphaned works is recorded in free access databases. That actually contradict to Art. 5 The Berne Convention.

At the same time, some of these databases are criticized due to the small number of included works (just books and manuscripts), open access just to

\footnotetext{
${ }^{28}$ Siso-Calvo, B., Arquero-Avilés. R., Marco-Cuenca G., Cobo-Serrano, S. Is There a Solution to the Orphan Works Problem? Exploring the International Models. In: Chowdhury G., McLeod J., Gillet V., Willett P. (eds) Transforming Digital Worlds. iConference (Springer), vol. 10766, 2018, pp. 638-644.

${ }^{29}$ Казарян К. Трансформаџия авторского права в интернете: зарубежные тенденции, бизнесмодели, рекомендации для России, Под ред. И. Засурского и В. Харитонова. М.: «Ассоциация интернет-издателей», 2013, [Kazarian, K., Transformation of copyright on the Internet: foreign trends, business models, recommendations for Russia, 2013. Edited by I. Zasursky and V. Kharitonov, Internet Publishers Association, 384].
} 
authorized users, limitation to use and exhausting procedure ${ }^{30}$. Furthermore, criteria of accuracy of conducting the diligent search are stated to be flexible ${ }^{31}$.

As the diligent search should be carried out to each orphan work in case of digitization of the collection of works, so the procedure is exhausted and time consuming to provide it for the library or museum ${ }^{32}$. Given the exhausting procedure, using autonomous technology are likely to solve the problem. As the using blockchain technology are considered to be highly effective to overcome problems relating databases and ledgers as the recorded would stay forever and could not be modified in system. One more advantage of applying Blockchain to orphan works is that every search of work would be stay in system, like Google search ${ }^{33}$.

The digitization and necessity of dissemination of cultural heritage has influenced on the European Community's decision to allow the free access and free use of a significant number of copyrighted works for non-commercial purposes by launching Europeana digital library project ${ }^{34}$.

The recommendations proposed by Ian Hargreaves in his report in 2011 was adopted in 2013 and the amendments to The UK Copyright, Designs and Patents Act $(1988)^{35}$ are made. The amendments are follows: the non-exclusive licenses for the using of orphan works are issued, if the prospective user conducted a diligent search and does not find copyright holder ${ }^{36}$. The licensing scheme applies to all types of copyrighted works within the UK, unlike the Directive 2012/28, applies to the commercial using of works only. Thus, the UK is the first country in the world where both commercial and out-of-commercial using of orphan works were allowed in 2013, on condition conducting the diligent search and the licensing payment.

Following the public consultation in the UK, on October 29, 2014, the rules governing the conditions for issuing individual licenses for orphan works were introduced. The rules contain requirements of the carrying out diligent search and

${ }^{30}$ Goldenfein, J., Hunter, D. Blockchains, Orphan Works, and the Public Domain. Columbia Journal of Law \& The Arts, 1 (41), 2018, pp. 1-43.

${ }^{31}$ Martinez, M., Terras, M., Not Adopted: The UK Orphan Works Licensing Scheme and how the crisis of copyright in the cultural heritage sector restricts access to digital content. Open Library of Humanities, 5(1), 2019, pp. 1-51. [online], available at: https://doi. org/10.16995/olh.335 [Accessed 6 June. 2021].

${ }^{32}$ Fanea-Ivanovici, M., Culture as a prerequisite for sustainable development. An investigation into the process of cultural content digitisation in Romania, Sustainability, 10, 2018, pp. 1859.

33 ІТ-право: теорія та практика: навч. посіб./ авт. кол.; за ред. Є.О. Харитонова, О.І. Харитонової. Одеса: Фенікс, 2017, p. 91-92. [Kharytonov, U.O., Kharytonova IT-law: theory and practice O.I. Odessa: Fenix, 2017, pp. 30-40]; Рузакова О.А., Гринь Е.С. Применение технологии Blockchain $\kappa$ систематизации результатов интеллектуальной деятельности, "Вестник Пермского университета. Юридические науки”, 38, 2017, pp. 508-520. [Ruzakova O.A., Grin, E.S. Application of Blockchain technology to systematization of the results of intellectual activity. Bulletin of Perm University. Legal sciences, 38, 2017, pp. 508-520]; Supra note 28.

${ }^{34}$ Marta-Christina Suciu, Mina Fanea-Ivanovici, "The European digital library (Europeana). Concerns related to intellectual property rights", Juridical Tribune (Tribuna Juridice), 8(1), 2018, pp. 244-259.

${ }^{35}$ United Kingdom, Copyright, Designs and Patents Act, 1988, [online], available at: https://www. legislation.gov.uk/ukpga/1988/48/ contents [Accessed 30 May. 2021].

36 United Kingdom, The Enterprise and Regulatory Reform Act, 2013, [online], available at: https://www.legislation.gov.uk/ukpga/ 2013/24/contents/enacted [Accessed 30 May. 2021]. 
databases where it should be conducted. The agency has developed a series of industry guides to help users conduct a diligent search. According to the rules, a searcher who has paid a fee may be granted a non-exclusive license to use the work within the UK for up to seven years with the possibility of renewal. If a rights holder does not declare authorship of the work and does not demand a fee for the use of works during this time, the Copyright Office may use the money to finance social, cultural and educational activities.

The legal regulation of orphan works is based on the following principles and main steps that have to be performed by a prospective user: conducting diligent search in accordance with the law requirements; appealing to the authorized state body by the applicant; payment of the established contribution by the applicant; granting rights to use the work. Based on this institution, it can be called state licensing.

Along with individual licensing, collective licensing is considered to be effectively scheme to use orphan works legally. Collective licenses are issued by collective rights management organization who collectively represent a number of the rights' holders. In this scheme prospective user needn't to obtain permission for each work from every rights holder. The use of collective licenses is believed to solve the problem of digitizing and opening access to collection of works of cultural institutions. There are restrictions of using collective licensing to orphan works. Being issued on behalf of the members of a collective rights management organization, the collective license does not apply the works whose rights holders are not members of collective rights management organizations.

The collective licensing scheme based upon the mandate received from the member of the collective rights management organizations. That's way this scheme does not provide representation of the interests of not member of collective rights management organizations. A similar situation concern orphan works.

The problem of outsiders, authors who are not members of collective rights management organization are supposed to solve by applying to extended collective licensing scheme which introduced in the Scandinavian countries 50 years ago. The extended collective licensing scheme applies to the works of not members of the organization, to the works of persons who are not participants, and to orphan works, thus solving the problem of outsiders ${ }^{37}$.

However, the obligatory condition for obtaining extended collective licensing is the absence of other license agreements, is the rights must not be transferred to a third party. The agreement is distributed and is subject to execution by persons not members of the collective rights management organizations, and if they wish to restrict the use of the work, they must, in accordance with the law, prohibit the use of their works or set a fee for their use. As the decision of extend the licensing is based on of free negotiations, during which the exclusive rights and rights arising from the agreements are recognized, as a result of every rights holders have the same rights and opportunities.

${ }^{37}$ Supra note 22. 
Using the extended collective licensing scheme are reported to be effective measure of the way to ensure the open access to the works in the digital landscape (WIPO Emerging Copyright Licensing Modalities, 2010).

Based on the above the extended collective licensing scheme are likely to be the most effective measure of the way to ensure the open access to the works with unknown author. In this way established the extended collective licensing scheme in Ukrainian law are expected to permit legal using the works with unknown author.

Given the high cost of digitizing of cultural institutions' funds, the EU Commission and national governments support the participation of national libraries at the Public Private Partnerships system, where the project is made possible by a private partner. In this case, both the library and the private partner will need to obtain a license to use documents and files ${ }^{38}$.

\subsection{Prospects of legalization of the orphan works in Ukraine}

Ukraine is not in large scale of the digitization of the collections of libraries, museums' archives, educational institutions and the problem of legalization of orphan works are not regulated by the copyright law.

At present, the legislation of Ukraine does not exist any provision of the orphan works and does not identify them. Any sort of using of the copyright object, whether it is not fair use, needs to obtain the permission of the copyright owner (or organization of collective management of copyright) according to Art. 21-25 of The Ukrainian Law "On Copyright and Related Rights" ${ }^{39}$. If permission is not obtained or prospective user cannot find the author or right holder, such actions qualify as copyright infringement and publisher's excuse can not be considered as redemption if the author is plead. Nevertheless, if the author or right holder did not find out about the fact of violation his right, he would not take measures to protect it.

Recently, one of the publishers has published book with a warning of the inability to find and identify the author and made a suggestion to apply to him regarding copyright the translation of the book. This situation has attracted the attention of the community. According to the paragraph (5) part 3 of Art. 15 of The Ukrainian Law "On Copyright and Related Rights" the creation of a derivative work and the translation of the work are required to get permission of the author or copyright holder. Publishers should still be more carefully and such negligence as publication with the warning does not release on liability of violation of intellectual property rights ${ }^{40}$.

38 Organisation for Economic Co-operation and Development. Recommendation of the Council on Principles for Public Governance of Public-Private Partnerships, 2012 [online], available at: https://www.oecd.org/governance/budgeting/PPP-Recommendation.pdf [Accessed 26 May. 2021].

39 Про авторське право і суміжні права: Закон Верховної Рада України від 23 грудня 1993 року № 3792-XII [Ukraine, On Copyright and related rights, Verkhovna Rada of Ukraine. 1993], [online], available at: https://zakon.rada.gov.ua/laws/show/3792-12\#Text [Accessed 30 May. 2021].

40 Пошелюжная К., Видавництво яке не змогло зайти правовласників для придбання перекладу, порушило авторське право. Липень 7, 2020 [Poshelyuzhna, K. Publishers, who could not find the right holders to purchase the translation, violated copyright, Lawyers. last modified July 9, 2020], 
Nevertheless, in light of the recodification of the Civil Legislation the Government of Ukraine is focused on developing digital infrastructure ${ }^{41}$. The digitization is considered to be aim on creating benefits and improving the quality of services in various spheres of everyday life, including culture and education (The concept of development of the digital economy and society of Ukraine 2018-2020 and approval of the action plan for its implementation) $)^{42}$.

This is way the seek solution of the legal using of the orphan works is up to date in Ukraine. Moreover, due to the outbreak of COVID 19, lockdown, limited access to the cultural institution funds and the emergence of certain initiatives that aimed at digitalization of funds are put legalization of the orphan works on the agenda.

In order to improve the legislation in the field of copyright of Ukraine and to provide the mechanisms of legalization of using orphan works, the open register of orphan works is proposed to establish and to provide open access to them ${ }^{43}$; to bound the cultural institutions, and owners of private collections to provide information for inclusion in the Unified Register; granted organizations of collective management of rights to identify species, their authors or rights holders ${ }^{44}$.

In order to improve legal regulation of copyright in Ukraine a Draft Law "On Copyright and related frights" has been presented recently by Ministry for Development of Economy, Trade and Agriculture of Ukraine ${ }^{45}$. The Draft Law proposed to add a definition of orphan works as a work (performance of a phonogram, videogram) of the author or the copyright holder is not identified, or even if one of them is not identified and found, despite a diligent search of them was conducted.

In accordance with the Draft Law "On Copyright and Related Rights" the use of orphan works is expected to allow by means of reproduction (for the purpose of digitization, open access, indexing, cataloging, preservation or restoration), as

[online], available at: HTTPS:/PRAVO.UA/VIDAVNICTVO-JAKE-NE-ZMOGLO-ZNAJTIPRAVOVLASNIKIV-DLJA-PRIDBANNJA-PEREKLADU-PORUSHILO-AVTORSKE-

PRAVO-JURISTI/ [Accessed 30 May. 2021].

41 Харитонова, Є., Харитонової, О., Рекодифікація ичиільного законодавства в контексті інтеграиії України у правовий простір ЄС, Часопис ичивілістики, (34), 2020, pp. 6-10. [Kharytonov, Y., Kharytonova. O. Recodification of civil law in the context of Ukraine's integration to the EU legal framework. The Journal of Civil Studies, (34), 2020, pp. 6-10].

42 Концепція розвитку цифрової економіки та суспільства України на 2018-2020 роки та затвердження плану заходів щодо іiі реалізації: Розпорядження Кабінети Міністрів України від 17 січня 2018 р. № 67-p [Ukraine, 2018, The concept of development of the digital economy and society of Ukraine 2018-2020 and approval of the action plan for its implementation. Order of the Cabinet of Ministers of Ukraine, January 17, 2018]. [online], available at: https://zakon.rada.gov.ua/laws/show/67-2018-p\#Text [Accessed 30 May. 2021].

${ }^{43}$ Supra note 10.

${ }^{44}$ Supra note 11.

${ }^{45}$ Міністерство розвитку економіки, торгівлі та сільського господарства України. Проект Закону України «Про авторське право та суміжні права», (10 березня, 2020), [Ukraine, Ministry for Development of Economy, Trade and Agriculture of Ukraine. A Draft Law "On Copyright and related rights"], (10 march, 2020), [online], available at: https://www.me.gov.ua/?lang=en-GB [Accessed 30 May. 2021]. 
well as open access after taking actions by prospective user to identify the author (a rights holder) and to conduct diligent search, which did not lead to the identification or finding identified subjects.

The status of orphan works is believed to obtain to work which published in Ukraine namely: works published in books, magazines, newspapers or other part of collected works of non-profit organizations deal with the protection of cultural heritage; audiovisual works contained in the collections of these organizations; audiovisual works were created by television and radio state or local selfgovernment bodies before December 31, 2002 (inclusive) and stored in their archives.

The way of returning the orphan works its status are provided in The Draft Law as well. If the author or copyright holder declares a motivated statement of his copyright, with reference to the grounds of such rights, as well as contact information that allows to contact the copyright entity to obtain permission to use the work, an orphan work will lose it's an orphan status. Hereby the work that has lost the status of an orphan work is protected in accordance with Copyright Law.

The provision of Law of the legislation of the orphan works is believed to become a significant success on the way to reforming copyright legislation in Ukraine.

However, there are shortcomings in The Draft Law. The digitization, open access to the public, indexing, cataloging, preservation or restoration of cultural institution funds are assumed to be for non-commercial way of using of orphan works. The commercial using of orphan works are excluded under The Draft Law. Both the list of databases where the diligent search should be conducted and obligatory prove that user provided diligent search in good faith are not defined. Any sort of compensation of damages or liability has not been established for not conducting diligent search in good faith. Moreover, the article refers to the procedure and conditions of the permitted usage of orphan works which should be determined by Ukrainian parliament. And it has not been a draft of order this procedure yet.

This legislative initiative is unlikely to be effective if it comes to force. The experience of European countries should be taken into consideration in the way of recodification of civil law and reforming the legislation in the field of intellectual property in Ukraine.

\section{Conclusions}

The paper provided brief statement of genesis of rising amount of orphan works, reason of their disappearing from the World Heritage Fund and way of solving problem relating to works with unknown author in different states. Besides, the urgent need to bring legislation up to date and to implement the mechanisms of legalization of use orphan works was caused by the outbreak and the derogation access to the cultural institutions' funds.

The decision was made that ensuring open access and dissemination of cultural heritage had led to large-scale digitization of the collections of libraries, 
museums' archives, educational institutions, film funds and broadcasting organizations and had risen the issue of using works with unknown author in the EU and US.

Attempts to solve the problem of legal using orphan works are carried out in different legal systems. As the research shown there is no single solution of legalization of orphan works. Neither solution of types of works that can be accessed and ways of possible use nor the possibility of commercial using of orphan works and others.

The conclusion was made about main trends in regulation of orphan works: the requirement to conduct a diligent search of a rights holder, which may not lead to establishment of his identity and / or location; the development of repository banks of orphan works for conducting diligent search; the right of rights holder to restore his rights and receive compensation for the using of work for a certain period of time; the limitation of the compensation for using an orphan works by reasonably limited compensation on condition of compliance of law.

Analysis of the schemes of legalization orphan works showed that solving the problem at country level did not bring effect in digital age. The negotiations on the establishment of a protection of orphan works are reported to conduct at the interstate level, since any national and regional level, firstly, will not solve the problem of cross-border relations in digital area, and, secondly, they will violate the usual regime of exclusive copyright protection. Since the amount of orphaned works and its high value for society, the solution of this problem must be solved at the international level.

Thus, the legal regulation of the mechanisms of legalization of orphan works should be carried out with the world experience and should become one of the priority vectors of reforming the legislation in the field of intellectual property in Ukraine.

\section{Bibliography}

1. Authors Guild, Inc. v. Google Inc., No. 13-4829-cv (2d Cir. Oct. 16, 2015) [online], available at: https://fairuse.stanford.edu/case/authors-guild-v-google-inc/ [Accessed 28 May. 2021].

2. Allard Ringnalda, Orphan Works, Mass Rights Clearance, and Online Libraries: The Flaws of the Draft Orphan Works Directive and Extended Collective Licensing as a Solution, Medien und Recht International vol. 8, 2011, pp. 3-10, [online], available at: https://ssrn.com/abstract=2369974.

3. Антопольский А.Б., Ефременко Д.В. Инфосфера общественных наук России: монография. Берлин: “Директ-Медиа”, 2017, [Antopolsky, A.B., Efremenko, D.V. Infosphere of social sciences of Russia: monograph. Berlin: Direct-Media, 2017].

4. Borghi, M., Erickson, K., Favale, M. With Enough Eyeballs All Searches Are Diligent: Mobilizing the Crowd in Copyright Clearance for Mass Digitization, 2016, 16 Chi. Kent J. Intell. Prop. 135 available at: http://scholar ship.kentlaw.iit.edu/ ckjip/vol16/iss $1 / 6$.

5. Center for the Study of the Public Domain, Duke Law School [online], available at: http://www.1aw. duke.edu/cspd/orphanworks.Html [Accessed 10 May. 2020]. 
6. Hansen, David R., Orphan Works: Definitional Issues, Berkeley Digital Library Copyright Project, White Paper, 1, 2011, [online], available at: http://ssrn.com/abstract=1974614. [Accessed 5 june. 2021].

7. Hansen, David R., Orphan Works: Causes of the Problem (April 10, 2012). Berkeley Digital Library Copyright Project White Paper, 3, 2012, [online], available at: SSRN: https://ssrn.com/abstract=2038068.

8. Давидова І.В. Блокчейн та категорія правочину. Актуальні проблеми циивілістики у изифрову добу. за ред. С.О. Харитонова, О.І. Харитонової. 2018, С. 59-92 Одеса: Юридична література, [Davydova, I.V. Blockchain and transaction category. Actual problems of civilization in the digital age. Edited by Kharytonov, U.O., Kharytonova. 2018, pp. 59-92, Odessa: Legal Literature].

9. Интервью генерального секретаря и директора IFFRO Olav Stokkmo, [Collective management of rights: upcoming trends. Interview with Olav Stokkmo] 2013, [online], http://copyrus.org/stati/collective_ management_trends.html [Accessed 25 April. 2021].

10. European Parliament and European Council, Directive of 25 October 2012 on certain permitted uses of orphan works [online], available at: https://www.eifl.net/resources/ european-orphan-works-directive-eifl-guide [Accessed 17 May. 2021].

11. European Commision, The Memorandum of Understanding (MoU) key principles on the digitization and making available of out-of-commerce works, 20 September 2011, [online], available at: https://www.jipitec.eu/issues /jipitec-2-3-2011/3180/mou.pdf [Accessed 27 April. 2021].

12. Fanea-Ivanovici, M., Culture as a prerequisite for sustainable development. An investigation into the process of cultural content digitisation in Romania, Sustainability, 10, 2018, pp. 1859.

13. Goldenfein, J., Hunter, D. Blockchains, Orphan Works, and the Public Domain. Columbia Journal of Law \& The Arts, 1 (41), 2018, pp.1-43.

14. Hargreaves, I. Digital. Opportunity. A Review of Intellectual Property and Growth. An Independent Report. May 2011, [online], available at: https://orca.cf.ac.uk/30988 /1/1_Hargreaves_Digital\%20Opportunity.pdf [Accessed 13 May. 2021].

15. Handbook on Copyright and Related Issues for Libraries, 2009 [online], available at: https://eifl.net/sites/ default/files/resources/201409/handbook_rus_05.pdf [Accessed 10 May. 2021].

16. Проект Google Books - несостоявшаяся революция в авторском праве? last modified November 21, 2012 [Is the Google Books project a failed copyright revolution?] 2012, [online], available at: http://lexdigital.ru/ 2012/069/ [Accessed 11 May. 2021].

17. ІТ-право: теорія та практика: навч. посіб./ авт. кол.; за ред. С.О. Харитонова, О.І. Харитонової. Одеса: Фенікс, 2017, p. 91-92. [Kharytonov, U.O., Kharytonova ITlaw: theory and practice O.I. Odessa: Fenix, 2017, pp. 30-40].

18. Казарян К. Трансформация авторского права в интернете: зарубежные тенденции, бизнес-модели, рекомендации для России, Под ред. И. Засурского и В. Харитонова. М.: «Ассоциация интернет-издателей», 2013, [Kazarian, K., Transformation of copyright on the Internet: foreign trends, business models, recommendations for Russia, 2013. Edited by I. Zasursky and V. Kharitonov, Internet Publishers Association, 384].

19. Харитонова, Є., Харитонової, О., Рекодифікація циивільного законодавства в контексті інтеграції України у правовий простір ЄС, Часопис ичивілістики, (34), 2020, pp. 6-10. [Kharytonov, Y., Kharytonova. O. Recodification of civil law in the 
context of Ukraine's integration to the EU legal framework. The Journal of Civil Studies, (34), 2020, pp. 6-10].

20. Козлова Н.В., Косовец А.А., Ворожевич А.С. Электронные библиотеки научнообразовательных организаций: правовые проблемы создания и деятельности, Вестник Московского университета, 11 (6), 2015, 50-64, [Kozlova, N.V., Kosovets, A.A., Vorozhevich, A.S. Electronic libraries of scientific and educational organizations: legal problems of creation and activity, Moscow University Bulletin. Series 11. Law, (6), 2015, pp. 50-64].

21. Kyryliuk, A., Baadzhy, N., Honhalo, R., Kapustina, N., \& Galupova, L. Protection of copyright on the Internet. Amazonia Investiga 8(24), 2019, pp. 464-470.

22. Левова И.Ю. Сиротские произведения в России: статус, пути решения проблемы, Общественное достояние. Как открыть доступ к культуре и знаниям: сборник, М.: Екатеринбург: Ассоциация интернет-издателей, 2016. С. 49-88, [Levova, Y.Yu., Vynnyk, D.V., Moyseeva, A.Yu. Orphan works in Russia: status, ways to solve the problem. Yekaterinburg: Association of Internet Publishers, 2016, pp. 49-88].

23. Lifshitz-Goldberg, Y., Orphan Works. WIPO Seminar. Lecture Summary, 2010, [online], available at: http://www.wipo.int/edocs/mdocs/sme/en/wipo_smes_ge_ 10/wipo smes ge 10 ref theme11 02.pdf [Accessed 14 May. 2021].

24. Suciu, M., Fanea-Ivanovici, M., "The European digital library (Europeana). Concerns related to intellectual property rights", Juridical Tribune - Tribuna Juridica, 8(1), 2018, pp. 244-259.

25. Martinez, M., Terras, M., Not Adopted: The UK Orphan Works Licensing Scheme and how the crisis of copyright in the cultural heritage sector restricts access to digital content. Open Library of Humanities, 5(1), 2019, pp. 1-51. [online], available at: https://doi.org/10.16995/olh.335 [Accessed 6 June. 2021].

26. Михайлов, К., Сиротские произведения: в поисках правового режима. Право интеллектуальной собственности: Сб. науч. тр. Центр социал. науч.-информ. исслед. Москва, 2017, С. 59-65. [Mikhailov, K., Orphan works: in search of a legal regime. Intellectual Property Law: Scientific Digest, Center for social. scientificinform, Moscow State University, 2017, pp. 59-65].

27. Nekit, K. Tokareva, V. Zubar, V. Artificial intelligence as a potential subject of property and intellectual property relations. Ius Humani. Law Journal 9 (1), 2020, pp. 231-250.

28. Organisation for Economic Co-operation and Development. Recommendation of the Council on Principles for Public Governance of Public-Private Partnerships, 2012 [online], available at: https://www.oecd.org/gover nance/budgeting/PPPRecommendation.pdf [Accessed 26 May. 2021].

29. Піхурець О. В. Розвиток правового регулювання відносин, пов'язаних із використанням "сирітських творів" в Украӥні та краӥнах Європейського Союзу, "Науковий вісник Ужгородського національного університету", 44(1), 2017, С. 81-86. [Pihurets, O.V. Development of legal regulation of relations related to the use of "orphan works" in Ukraine and the European Union. Scientific Bulletin of Uzhhorod National University, 44(1), 2017, pp. 81-82].

30. Піхурець О.В. Проблеми використання "сирітських творів", Проблеми цивільного права та процесу: тези доп. учасників наук.-практ. конф., присвяч. світлій пам'яті О. А. Пушкіна, Харків: ХНУВС, 2017. С. 201-204. [Pihurets, O.V. Problems of using "orphan works". Problems of civil law and civil process: abstracts of reports of participants of the scientific-practical conference dedicated to the memory of OA Pushkin, 2017, pp. 201-204]. 
31. Пошелюжная К., Видавництво яке не змогло зайти правовласників для придбання перекладу, порушило авторське право. Липень 7, 2020 [Poshelyuzhna, K. Publishers, who could not find the right holders to purchase the translation, violated copyright, Lawyers. last modified July 9, 2020], [online], available at: HTTPS://PRAVO.UA/VIDAVNICTVO-JAKE-NE-ZMOGLO-ZNAJTIPRAVOVLASNIKIV-DLJA-PRIDBANNJA-PEREKLADU-PORUSHILOAVTORSKE-PRAVO-JURISTI/_[Accessed 30 May. 2021].

32. Пузин, Р.С., Проблема перехода сиротских произведений в общественное достояние “Вестник Самарской гуманитарной академии”, 1 (20), 2018, pp. 152160 [Puzin, R.S. The problem of the transition of orphan works to the public domain. Bulletin of the Samara Humanitarian Academy, 1(20), 2018, pp. 152-160].

33. Рузакова О.А., Гринь Е.С. Применение технологии Blockchain к систематизации результатов интеллектуальной деятельности, "Вестник Пермского университета. Юридические науки”, 38, 2017, pp. 508-520. [Ruzakova O.A., Grin, E.S. Application of Blockchain technology to systematization of the results of intellectual activity. Bulletin of Perm University. Legal sciences, 38, 2017, pp. 508-520].

34. Randal C. Picker, The Google Book Search Settlement: A New Orphan-Works Monopoly? Journal of Competition Law and Economics, 5 (3), 2009, pp. 383-409.

35. Ryden, J. Legal restrictions and the digital library - is digital access to knowledge achievable? The IFLA World Library and Information Congress, August 28, 2013, [online], available at: http://library.ifla.org/223/13/198-ryden-en.pdf [Accessed 18 May. 2021].

36. Штефан О. О. Правовий режим використання сирітських творів Міжнародний науковий журнал «Інтернаука”. 2(2), 2017, C. 184-191 [Shtefan, E.E., Legal regime of use of orphan works, International scientific journal. Internauka, 2, 2017, pp. 184-191].

37. Siso-Calvo, B., Arquero-Avilés. R., Marco-Cuenca G., Cobo-Serrano, S. Is There a Solution to the Orphan Works Problem? Exploring the International Models. In: Chowdhury G., McLeod J., Gillet V., Willett P. (eds) Transforming Digital Worlds. iConference (Springer), vol 10766, 2018, pp. 638-644.

38. Токарева В.О. Окремі аспекти сирітских творів в умовах інтеграційних процесів, Jurnaluljuridic, 3, 2019, c. 97-101 [Tokareva, V.O. Some aspects of orphan works in the context of integration processes. Jurnaluljuridic, 3, 2019, pp. 97-101].

39. Про авторське право і суміжні права: Закон Верховної Рада України від 23 грудня 1993 року № 3792-XII [Ukraine, On Copyright and related rights, Verkhovna Rada of Ukraine. 1993], [online], available at: https://zakon.rada.gov.ua/laws/show/379212\#Text [Accessed 30 May. 2021].

40. Міністерство розвитку економіки, торгівлі та сільського господарства України. Проект Закону України «Про авторське право та суміжні права», (10 березня, 2020), [Ukraine, Ministry for Development of Economy, Trade and Agriculture of Ukraine. A Draft Law “On Copyright and related rights”], (10 march, 2020), [online], available at: https://www.me.gov.ua/?lang=en-GB [Accessed 30 May. 2021].

41. Концепція розвитку цифрової економіки та суспільства України на 2018-2020 роки та затвердження плану заходів щодо іï реалізації: Розпорядження Кабінети Міністрів України від 17 січня 2018 р. № 67-p [Ukraine, 2018, The concept of development of the digital economy and society of Ukraine 2018-2020 and approval of the action plan for its implementation. Order of the Cabinet of Ministers of Ukraine, January 17, 2018]. [online], available at: https://zakon.rada.gov.ua/laws/show/67-2018p\#Text [Accessed 30 May. 2021]. 
42. United Kingdom, The Enterprise and Regulatory Reform Act, 2013, [online], available at: https://www. legislation.gov.uk/ukpga/2013/24/contents/enacted_[Accessed 30 May. 2021].

43. United Kingdom, Copyright, Designs and Patents Act, 1988, [online], available at: https://www.legislation.gov. uk/ukpga/1988/48/contents [Accessed 30 May. 2021].

44. U.S. Copyright Office, Orphan Works and Mass Digitization. A report of the register of copyrights, June, 2015. [online], available at: www.copyright.gov [Accessed 30 May. 2021].

45. WIPO, Berne Convention for the Protection of Literary and Artistic Works, 1886, [online], available at: https://www.wipo.int/treaties/ru/ip/berne/index.html [Accessed 30 May. 2021].

46. WIPO, 2010, Emerging Copyright Licensing Modalities - Facilitating Access to Culture in the Digital. [online], available at: https://www.wipo.int/meetings/ru/ details.jsp?meeting_id=20209_[Accessed 30 May. 2021].

47. WIPO, 2011, Interview with Lawrence Lessig. WIPO Magazine. [online], available at: https://www.wipo.int/ wipo_magazine/en/2011/01/article_0002.html [Accessed 30 May. 2021]. 